\title{
PENGELOLAAN LIMBAH MEDIS (LIMBAH VAKSIN) COVID-19 \\ DI KOTA KENDARI TAHUN 2021
}

\author{
La Ode Ahmad Saktiansyah ${ }^{1}$, Nurmaladewi², Putu Eka Meiyana Erawan ${ }^{3}$, \\ La Ode Liaumin Azim ${ }^{4}$ \\ 1,2,3,4 Fakultas Kesehatan Masyarakat, Universitas Halu Oleo
}

\begin{abstract}
Ensuring healthy lives and promoting well-being for all at all ages by 2030 is the third Target of the SDGs. The targets include efforts to reduce deaths from non-communicable diseases including breast cancer. The incidence of breast cancer increases with age, but we can prevent this cancer and if detected early, we will get better treatment. Early detection through BSE which is carried out starting at the age of adolescence with increased vigilance and is believed to be able to reduce mortality from breast cancer. The general purpose of this study was to determine the role of peer groups in conducting early detection through breast self-examination (BSE) as an effort to prevent breast cancer. This research is a research with pre test and post test with control group design. The sampling technique is purposive sampling. Data collection using questionnaires through google forms, checklists and modules. Analysis using Paired Sample T-test with the result $0.000<(\alpha)$ 0.05. This shows that there is a significant difference between the average scores before and after being given breast cancer health education. The conclusion is that there is a significant increase between peer education and BSE practice skills in adolescent girls. Peer youth educators are considered more influential on BSE abilities than teachers. Active learning methods provided by peer educators can increase the ability of self-awareness of adolescents.
\end{abstract}

Keywords: Medical Waste, Vaccines, Covid-19

\section{A. PENDAHULUAN}

Berbagai Berbagai jenis limbah medis yang dihasilkan dari kegiatan pelayanan di rumah sakit dapat membahayakan dan menimbulkan gangguan kesehatan terutama pada saat pengumpulan, pemilahan, penampungan, penyimpanan, pengangkutan dan pemusnahan serta pembuangan akhir, (Rahono, dkk., 2010). Limbah yang dihasilkan dari upaya medis seperti rumah sakit merupakan jenis limbah yang termasuk dalam kategori Biohazard. Biohazard yaitu jenis limbah yang sangat membahayakan lingkungan, di mana sangat banyak terdapat buangan virus, bakteri maupun zat-zat yang membahayakan, (Pratiwi \& Maharani, 2013).

Terjadinya pandemi Covid-19 mengharuskan upaya yang masif dalam pencegahan dan penularan penyakit infeksi tersebut dengan berbagai macam cara. Prinsip pencegahan penularan penyakit infeksi Covid-19 adalah melalui pemutusan rantai host/penjamu/inang. Salah satu upaya yang dapat dilakukan adalah dengan pengelolaan limbah medis rumah sakit yang dikategorikan sebagai limbah Bahan Berbahaya dan Beracun (B3) dengan baik dan (Kementrian LH., 2015).

Limbah medis dimasa pandemi Covid-19 perlu dikumpulkan dan diolah secara tepat waktu, aman dan dengan cara yang efektif untuk meminimalkan penyebaran virus 
dan risiko pada manusia. Timbulan limbah medis padat meningkat secara eksponensial selama wabah covid-19. Data menunjukan bahwa kota-kota secara kolektif menyumbang sekitar 864,00 ton umum limbah medis padat ke Municipal Solid Waste (MSW) setiap hari. Landfilling masih merupakan salah satu Municipal Solid Waste (MSW) yang paling umum pilihan manajemen di negara berkembang Asia seperti India, Malaysia, Thailand, Bangladesh, Myanmar, dan Indonesia, (Kulkarni, 2020). Peningkatan pesat dalam jumlah dikonfirmasi kasus posisitif Covid-19 seiring dengan peningkatan jumlah limbah medis padat di Rumah Sakit (RS) (Peng, at al., 2020).

Data menunjukan bahwa limbah medis padat dibeberapa Ibukota negara Asia Tenggara sangat beragam selama pandemi Covid-19, dimana penghasil limbah tertinggi adalah Ibukota Fillipina yaitu Manila sebesar 280 t/d, ke dua adalah Ibukota Thailand yaitu Bangkok sebesar 210 t/, ke tiga adalah Ibukota Indonesia yaitu Jakarta sebesar $201 \mathrm{t} / \mathrm{d}$, ke empat adalah Ibukota Vietnam yaitu Ha Noi sebesar 160 t/d sedangkan yang terendah adalah Kuala Lumpur sebesar 154 t/d, (Nghiem, at al., 2020). Tren kenaikan jumlah timbulan limbah medis padat terjadi di seluruh negara di dunia. Selama wabah Covid-19 berlangsung di Provinsi Hubei, Tiongkok, tercatat kenaikan 6 kali timbulan normal limbah medis padat, dari 40 ton/hari menjadi 240 ton/hari (Shi J., dan W. Z. 2020).

Limbah medis padat di Rumah Sakit Indonesia juga turut meningkat selama pandemi Covid-19. Hal ini ditunjukan dari data Kemenkes menjelaskan bahwa limbah medis padat yang belum dikelola jumlahnya masih sangat besar. Volume limbah medis padat yang berasal dari 2.889 rumah sakit dan 9.884 puskesmas di Indonesia mencapai 290-an ton/hari., (Prasetiawan, 2020). Dari 2.889 rumah sakit di Indonesia, hanya 110 yang memiliki insinerator berizin. Kondisi ini mengakibatkan terbatasnya kapasitas pengolah limbah B3 medis yang baru mencapai 53,12 ton/hari. Ditambah dengan kapasitas jasa pengolalaan oleh pihak ketiga sebesar 187,90 ton/hari, sementara jumlah limbah B3 medis diprediksi mencapai 294,66 ton/hari (Deni, 2020).

Penanganan pasien Covid-19 di Indonesia membutuhkan perlengkapan medis yang lebih banyak seperti masker, kacamata, baju hazmat, sepatu boots dan sebagainya. Peningkatan limbah medis akan semakin meningkat seiring dengan pelaksanaan program vaksinasi Covid-19, potensi limbah vaksin Covid-19 di Indonesia menurut Kementerian Kesehatan, 2021 menjelaskan bahwa sebanyak 329,5 juta dosis vaksin Covid-19, rincian berat persatu dosis vaksin Covid-19 yaitu vial 10 gram, spuit 10 gram, kapas 2 gram dan jarum suntik 1 gram, sehingga berat satu dosis vaksin covid-19 sebanyak 23 gram.

Penanganan Limbah Medis B3 yang meningkat jumlah dan volumenya pada saat terjadi pandemik Covid-19 harus diantisipasi dengan baik dan benar agar tidak berpotensi menjadi sumber infeksi baru terhadap manusia. Beberapa panduan telah dikeluarkan oleh berbagai organisasi internasional untuk menangani timbulan limbah medis selama pandemik Covid-19. Standard penanggulangan limbah medis B3 Covid19 menggunakan pedoman yang dikeluarkan oleh WHO, sedangkan di Indonesia mengacu kepada Surat Edaran No. SE.2/MENLHK/PSLB3/3/2020 Tentang Pengelolaan Limbah Infeksius (Limbah B3) dan Sampah Rumah Tangga dari Penanganan Corona Virus Disease (COVID-19) tertanggal 24 Maret 2020 dan pedoman dari Kementerian Kesehatan 2021 tentang Standar Prosedur Operasional Pengelolaan Limbah Vaksinasi Covid-19 (Kemenkes, 2020). 
Data limbah medis di Sulawesi Tenggara yang berasal dari Rumah Sakit Rujukan (RSU Bahteramas) yang terletak di Kota Kendari menunjukan bahwa pada bulan Juli 2020 jumlah limbah medis yang dihasilkan sebanyak $3650 \mathrm{~kg}$, pada bulan Agustus 2020 sebesar $5623 \mathrm{~kg}$ dan pada bulan September $20207748 \mathrm{~kg}$ hal ini menunjukan bahwa volume limbah medis semakin meningkat (Profil RSU Bahteramas, 2020). Pelayanan vaksinasi Covid-19 di Kota Kendari juga dilakukan di Puskesmas Se Kota Kendari yaitu sebanyak Lima Belas Puskesmas, target pelaksanaan vaksinasi sebanyak 4151 dosis pada Maret 2021, hal ini akan meningkatkan volume limbah medis di Kota Kendari. Dengan demikian, penelitian ini bertujuan untuk mengetahui proses pengelolaan limbah medis (limbah vaksin Covid-19) di Puskesmas Se Kota Kendari pada tahun 2021

\section{B. TINJAUAN PUSTAKA}

Limbah medis padat merupakan barang atau bahan sisa hasil kegiatan yang tidak digunakan kembali yang berpotensi terkontaminasi oleh zat yang bersifat infeksius atau kontak dengan pasien atau limbah yang berasal dari pelayanan medik, perawatan gigi, farmasi, penelitian, pengobatan, perawatan, atau Pendidikan yang menggunakan bahanbahan yang beracun, infeksius, berbahaya atau membahayakan kecuali jika dilakukan pengamanan tertentu (Kementerian Kesehatan, 2020).

Limbah B3 di masa pandemi Covid-19 ialah barang atau bahan sisa hasil kegiatan yang tidak digunakan kembali yang berpotensi terkontaminasi oleh zat yang bersifat infeksius atau kontak dengan pasien dan/atau petugas di Fasyankes yang menangani pasien Covid-19, meliputi: masker bekas, sarung tangan bekas, perban bekas, tisu bekas, plastik bekas minuman dan makanan, kertas bekas makanan dan minuman, alat suntik bekas, set infus bekas, Alat Pelindung Diri bekas, sisa makanan pasien dan lain-lain, berasal dari kegiatan pelayanan di UGD, ruang isolasi, ruang ICU, ruang perawatan, dan ruang pelayanan lainnya (Kementerian Kesehatan, 2020).

Limbah yang bersumber dari fasilitas kesehatan rumah sakit maupun puskesmas dapat mencemari lingkungan masyarakat di sekitar fasilitas pelayanan kesehatan tersebut dan dapat menimbulkan masalah kesehatan. Hal ini dikarenakan limbah dari fasiltas kesehatan pelayanan kesehatan mengandung berbagai jasad renik penyebab penyakit pada manusia termasuk demam typoid, kholera, disentri dan hepatitis sehingga limbah tersebut harus diolah sesuai dengan pengelolaan limbah medis sebelum dibuang ke lingkungan, (Asrun, 2020).

Limbah medis rumah sakit maupun puskesmas dapat dianggap sebagai mata rantai distribusi penyakit menular apalagi dimasa pandemi saat ini mengingat penularan Coronavirus sangat cepat dan meresahkan dunia. Limbah biasa menjadi tempat tertimbunnya organisme penyakit dan menjadi sarang serangga dan tikus. Disamping itu, di dalam limbah juga mengandung berbagai bahan kimia beracun dan benda benda tajam yang dapat menimbulkan gangguan kesehatan dan cidera (Asrun, 2020).

\section{METODEPENELITIAN}

Penelitian menggunakan metode kuantitatif deskriptif. Pendekatan penelitian yang digunakan yaitu pendekatan deskriptif yakni menggambarkan kondisi yang sebenarnya tentang objek yang diteliti, menurut keadaan yang sebenarnya pada saat penelitian 
berlangsung. Subjek penelitian adalah subjek yang dituju untuk diteliti oleh peneliti. Penentuan subjek dalam penelitian ini menggunakan metode teknik purposive sampling yaitu pengambilan sampel dengan menetapkan karakteristik yang sesuai dengan tujuan penelitian, (Yusuf, 2016).

Penelitian ini subjek yang dimaksud adalah petugas pelaksana vaksinasi Covid-19 dan penanggungjawab limbah vaksin. Analisis kuantitatif dilakukan dengan mendeskripsikan data yang berkaitan dengan jumlah dan pengelolaan limbah medis (limbah vaksin Covid-19), adapun kriteria obejektif Kategori Baik jika memperoleh skor $>50 \%$ dan Kategori Buruk jika memperoleh skor $<50 \%$.

\section{HASILPENELITIAN}

Pengelolaan limbah medis (Limbah Vaksin Covid-19) di Puskesmas Se-Kota Kendari telah melewati proses pemilahan, pewadahan dan pengumpulan selanjutnya di serahkan ke pihak ke tiga meliputi pengangkutan, pemusnahan, dan pembuangan akhir. Berikut ini distribusi responden dalam pemilahan dan pengumpulan atau pewadahan limbah medis Covid-19:

\section{Pemilahan}

Tabel 1 Pemilahan limbah vaksin Covid-19 Se-Kota Kendari

\begin{tabular}{|c|c|c|c|c|c|c|}
\hline \multirow{3}{*}{ No } & \multirow{3}{*}{ Indikator Penilaian } & \multicolumn{4}{|c|}{ Pemilahan } & \multirow{3}{*}{ Ket. } \\
\hline & & \multicolumn{2}{|c|}{ Ya } & \multicolumn{2}{|c|}{ Tidak } & \\
\hline & & $\mathbf{n}$ & $\%$ & $\mathbf{n}$ & $\%$ & \\
\hline 1. & $\begin{array}{l}\text { Wadah limbah medis padat dan } \\
\text { non-medis padat terpisah }\end{array}$ & 45 & 100 & 0 & 0 & Kategori Baik \\
\hline 2. & $\begin{array}{l}\text { Penampung limbah medis padat } \\
\text { kuat, tahan karat, kedap air, } \\
\text { memiliki penutup yang rapat, } \\
\text { dan tahan terhadap benda tajam } \\
\text { dan runcing }\end{array}$ & 42 & 93,3 & 3 & 6,7 & Kategori Baik \\
\hline 3. & $\begin{array}{l}\text { Wadah limbah medis padat } \\
\text { dilapisi dengan kantung plastik } \\
\text { kuning }\end{array}$ & 27 & 60 & 18 & 40 & Kategori Baik \\
\hline 4. & $\begin{array}{l}\text { Melaksanakan pemilahan limbah } \\
\text { medis padat dan non medis } \\
\text { padat sebelum di buang }\end{array}$ & 42 & 93,3 & 3 & 6,7 & Kategori Baik \\
\hline 5. & 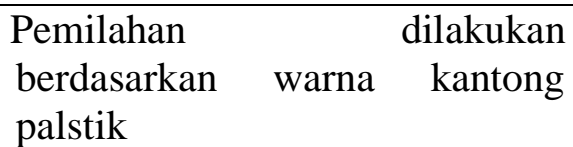 & 27 & 60 & 18 & 40 & Kategori Baik \\
\hline
\end{tabular}

Tabel 1 menunjukan bahwa sebanyak 15 puskesmas yang ada di Kota Kendari dari segi pemilahan limbah medis padat atau limbah vaksin Covid-19 semua dalam ketagori Baik yang meliputi menggunakan tempat yang terpisah antara limbah medis padat dan non medis, penampung limbah medis kuat, tahan karat, kedap air, memiliki tutup, tehan 
terhadap benda tajam dan runcing, penggunaan kantong plastik untuk melapisi wadah limbah dan penggunaan kantong plastik kuning dan hitam sebagai wadah limbah medis dan non medis

\section{Pengumpulan}

Pengumpulan/pewadahan limbah medis atau limbah vaksin Covid-19 di Puskesmas Se-Kota Kendari disajikan dalam tabel berikut :

Tabel 2. Pengumpulan/pewadahan limbah vaksin Kota Covid-19 Kota Kendari

\begin{tabular}{|c|l|c|c|c|c|l|}
\hline \multirow{2}{*}{ No } & \multicolumn{2}{|c|}{ Indikator Penilaian } & \multicolumn{3}{|c|}{ Pengumpulan } & \multirow{2}{*}{ Ket. } \\
\cline { 3 - 6 } & \multicolumn{2}{|c|}{ Ya } & \multicolumn{2}{c|}{ Tidak } & \\
\cline { 3 - 6 } 1. & $\begin{array}{l}\text { Troli pengumpulan limbah } \\
\text { medis padat dan non medis } \\
\text { dipisahkan }\end{array}$ & 28 & 62,2 & 17 & 37,8 & $\begin{array}{l}\text { Kategori } \\
\text { Baik }\end{array}$ \\
\hline 2. & $\begin{array}{l}\text { Terdapat kantong plastik } \\
\text { kuning pada tempat limbah } \\
\text { medis infeksius }\end{array}$ & 28 & 62,2 & 17 & 37,8 & $\begin{array}{l}\text { Kategori } \\
\text { Baik }\end{array}$ \\
\hline 3. & $\begin{array}{l}\text { Terdapat kantong plastik hitam } \\
\text { pada tempat sampah non } \\
\text { medis }\end{array}$ & 42 & 93,3 & 3 & 6,7 & $\begin{array}{l}\text { Kategori } \\
\text { Baik }\end{array}$ \\
\hline 4. & $\begin{array}{l}\text { Terdapat safety box untuk } \\
\text { limbah B3 }\end{array}$ & 45 & 100 & 0 & 0 & $\begin{array}{l}\text { Kategori } \\
\text { Baik }\end{array}$ \\
\hline 5. & $\begin{array}{l}\text { Terdapat label Biohazard pada } \\
\text { kantong plastik plastik limbah }\end{array}$ & 24 & 53,3 & 21 & 46,7 & $\begin{array}{l}\text { Kategori } \\
\text { Baik }\end{array}$ \\
\hline
\end{tabular}

Berdasakan Tabel 2 menunjukan bahwa sebanyak 15 puskesmas yang ada di Kota Kendari dari segi penimbunan limbah medis dan non medis termasuk limbah dari kegiatan vaksinator dari beberapa poin pertanyaan semua dalam kategori Baik dalam hal pengumpulan tersebut yang meliputi penggunaan troli, kantong plastik kuning dan hitam serta safety box.

\section{Pengangkutan, Pemusnahan Dan Pembuangan Akhir}

Pengangkutan,. Pemusnahan dan pembuangan akhir limbah medis atau limbah vaksin Covid-19 di Puskesmas Se-Kota Kendari disajikan dalam tabel berikut :

Tabel 3. Pengangkutan, Pemusnahan Dan Pembuangan Akhir limbah vaksin Covid-19 Se-Kota Kendari

\begin{tabular}{|c|l|ll|}
\hline No & \multicolumn{1}{|c|}{$\begin{array}{c}\text { Tahapan Pengelolaan Limbah Vaksin } \\
\text { Covid-19 }\end{array}$} & \multicolumn{3}{|c|}{ Keterangan } \\
\hline 1 & Pengangkutan & $\begin{array}{l}\text { Pihak Ketiga (PT Mitra } \\
\text { Hijau) }\end{array}$ \\
\hline 2 & Pemusnahan & & \\
\hline 3 & Pembuangan Akhir & & \\
\hline
\end{tabular}


Tabel menunjukan bahwa pada pengelolaan limbah medis atau limbah vaksin Covid-19 pada tahap pengangkutan, pemusnahan dan pembuangan akhir dilakukan oleh pihak ke tiga (PT Mitra Hijau).

\section{E. PEMBAHASAN}

Pengetahuan Pajanan limbah layanan kesehatan dapat mengakibatkan penyakit atau cidera petugas kesehatan, pasien, pengunjung dan masyarakat disekitar lingkungan Limbah medis merupakan porsi yang lebih besar dari infeksi limbah, yang berpotensi berbahaya karena kemungkinan berisi agen patogen. Pengelolaan limbah harus dilakukan dengan benar dan efektif serta memenuhi persyaratan sanitasi. Sebagai suatu yang tidak digunakan lagi, tidak disenangi, dan harus dibuang maka limbah tentu harus dikelola dengan baik. Pengelolaan limbah merupakan kegiatan yang sistematis, menyeluruh dan berkesinambungan yang meliputi pengurangan, penanganan dan pemusnahan limbah.

Pengelolaan Limbah medis telah diatur dalam Permen LH. RI No. 56 Tahun 2015 yang meliputi : pengurangan dan pemilahan, penyimpanan, pengangkutan, pengolahan dan pemusnahan (penimbunan atau penguburan). Untuk limbah medis dari penanganan pasien COVID-19, pengelolaanya diatur dalam Panduan Pengelolaan Limbah Rumah Sakit Rujukan, Rumah Sakit Darurat dan Puskemas yang Menangani Pasien COVID-19. Secara spesifik, pedoman ini mengatur APD bagi petugas. (pewadahan, pengangkutan, incinerator, transporter dan pengolah limbah COVID-19), label serta sarana limbah COVID-19 dengan perlakuan dan khusus (TPS, trolly dan bin).

Peralatan medis yang telah digunakan untuk pasien harus dimusnahkan lantaran sangat berbahaya bagi kesehatan masyarakat. Limbah medis seperti jarum suntik harus dimusnahkan, pemusnahannya tidak sembarangan, tapi menggunakan alat Incenerator. Bahkan hasil pemusnahannya tidak dibuang sembarangan. Ketentuan ini juga berlaku di lingkungan puskesmas yang sudah seharusnya memiliki alat tersebut, karena di lingkungan puskesmas juga memiliki limbah berbahaya. kalau tidak ada alat untuk pengolahan limbah, maka puskesmas tersebut harus membawa limbah berbahaya ini ke rumah sakit jika sudah tersedia, termasuk jarum suntik dan obat-obatan ke rumah sakit untuk dimusnahkan atau dihancurkan.

Pengelolaan limbah medis padat atau limbah vaksin Covid-19 di puskesmas SeKota Kendari menggunakan pedoman Permen LH. RI No. 56 tahun 2015 dan menggunakan Peraturan Menteri Kesehatan No 1204 Tahun 2004.

\section{Pemilahan}

Pemilahan adalah kegiatan memilah atau memisahkan antara limbah medis dan non medis, serta antara limbah medis jarum suntik dan limbah medis lainnya. Pengelolaan limbah medis diwajibkan melakukan pemilihan menurut limbah dan menyimpannya di dalam kantong plastik yang berbeda-beda menurut karekteristik atau jenis limbahnya. Limbah umum dimasukkan ke dalam plastik berwarna hitam, limbah infeksius ke dalam kantong plastik kuning, (Ningrum Dan Tualeka, 2019).

Pemisahan limbah medis sesuai Permen LHK Nomor 56 tahun 2015 wajib dilakukan oleh setiap penghasil limbah medis. Menurut Keputusan Menteri Kesehatan Nomor 1204 Tahun 2004 disebutkan bahwa setiap penghasil limbah wajib untuk 
memilah limbah medis dan ini dilakukan mulai dari sumber dimana limbah itu dihasilkan.

Menurut PerMenLHK RI No. P.56 Tahun 2015, pemilahan pada sumber (penghasil) limbah merupakan tanggung jawab penghasil limbah. Pemilahan harus dilakukan sedekat mungkin dengan sumber limbah, dan harus dilakukan selama penyimpanan, pengumpulan dan pengangkutan. Untuk efisiensi pemilahan limbah dan mengurangi penggunaan kemasan yang tidak sesuai, penempatan dan pelabelan pada kemasan harus dilakukan secara tepat. Penempatan kemasan secara bersisian untuk limbah non-infeksius dan limbah infeksius akan menghasilkan pemilahan limbah yang lebih baik.

Pemilahan limbah medis dilakukan untuk memudahkan dalam pengelompokan jenis limbah medis berdasarkan kategori agar dapat dilakukan pengelolaan yang sesuai dengan jenis limbah. Pemilahan yang dilakukan sejak awal juga dilakukan agar dapat mengurangi biaya yang diperlukan dalam pengelolaan limbah medis. Limbah medis yang dibuang dengan limbah non medis akan dapat mengontaminasi limbah non medis lainnya sehingga dapat berbahaya bagi kesehatan apabila terpajan langsung oleh manusia, (Rosihan, 2018).

Hasil penelitian menunukan bahwa dalam pemilahan limbah medis padat telah disediakan tempat sampat yang berbeda-berbeda berdaasarkan jenis sampah yang dihasilkan. Adapun tempat atau wadah yang digunakan untuk mengumpul limbah medis adalah limbah wadah pijakan yang dilapisi kantong plastik kuning dan hitam serta safety box. Limbah yang berkaitan dengan kegiatan vaksinasi seperti jarum suntik disimpan di safety box. Sebanyak 45 responden melakukan pemilahan limbah berdasarkan peraturan yang berlaku baik dari pedoman Kemenkes No. 1204/2004 dan MLHK No 56/2015. Hal ini didukung dengan hasil menunjukan bahwa proses pengelolaan limbah vaksin mulai dari proses pemilahan berdasarkan jenisnya hazmat disimpan di kantong palstik kuning dan handscoon, masker serta kain kasa juga disimpan di kantong kuning dan yang terakhir adalah jarum suntik disimpan dalam safety box. Limbah-limbah yang dihasilkan tersebut di kumpul di Tempat Penampungan Sementara dan diangkut oleh PT Mitra Hijau sebagai transporter limbah medis untuk dilakukan pengelolaan limbah lebih lanjut. Hasil penelitian ini sesuai dengan penelitian yang dilakukan oleh $\mathrm{X}^{18}$ Di Rumah Sakit Bahteramas menunjukan bahwa dalam pengelolaan limbah medis hanya beberapa tahap yang dilewati yaitu pemilahan, pewadahan, pengumpulan dan pengangkutan, lebih dari itu diserahkan ke pihak ke-tiga seperti pemusnahan, pembuangan akhir dan daur ulang. pada masingmasing ruangan telah disediakan tempat sampah berbahan fiber untuk pewadahan limbah infeksius dan limbah non infeksius serta telah dilengkapi dengan safety box, (Sarmin dkk., 2021). Berkaitan dengan pemilahan limbah medis puskesmas Se Kota Kendari penggunaan kantong plastik kuning sebagai tempat limbah medis sebanyak 60 $\%$ responden menggunakan kantong plastik kuning dan $40 \%$ responden tidak menggunakan kantong plastik kuning tetapi juga menggunakan kantong plastik merah dan juga dus-dus bekas. Berdasarkan fungsinya kantong plastik merah juga sebagai tempat limbah medis, terkait dengan penggunaan dus-dus bekas dalam pewadahan limbah medis tidak sesuai dengan Keputusan Mentri Kesehatan No. 1204 Tahun 2004 keberadaan dus-dus bekas tersebut peneliti dalam keadaan tidak sengaja ada ruangan terbuka yang bukan TPS yang dijadikan sebagai TPS limbah medis, di dalam dus-dus tersebut terdapat limbah botol vaksin. 


\section{Pengumpulan}

Pengumpulan limbah padat medis merupakan proses mengumpulkan limbah medis yang dihasilkan oleh setiap ruangan maupun pelayanan dalam lingkungan puskesmas. Wadah limbah medis adalah suatu jenis tempat limbah yang tersedia dan digunakan sebagai tempat membuang limbah, baik limbah medis maupun non medis yang memiliki kriteria sehingga layak digunakan sebagai wadah tempat limbah medis maupun non medis. Pewadahan yang digunakan oleh setiap rumah sakit adalah pewadahan yang betul-betul memperhatikan kelayakan atau memenuhi syarat kesehatan dengan pertimbangan bahwa wadah tersebut sesuai dengan standar kesehatan nasional yang ditetapkan dalam Permenkes No 1204/Menkes/SK/X/2004 dan mengacu pada standar WHO (World Health Organization) yaitu pewadahan sampah medis menggunakan label (warna kantong plastik/kontainer), sampah radioaktif menggunakan warna merah, sampah sangat infeksius menggunakan warna kuning, sampah/limbah infeksius, patologi dan anatomi menggunakan warna kuning, sampah sitotoksis menggunakan warna ungu, dan sampah/limbah kimia dan farmasi menggunakan warna cokelat, (Ajeng, 2018).

Hasil penelitian menunjukan bahwa di Puskesmas Se-Kota Kendari dalam mengumpulkan limbah medis atau limbah vaksin Covid-19 dengan menggunakan wadah tempat sampah pijakan, kantong plastik kuning dan hitam, safety box dan troli. Penggunaan troli sebagai pengangkut limbah medis ke TPS sebanyak 62,2\% sedangkan yang tidak menggunakan troli sebanyak $37,8 \%$, yang tidak menggunakan troli limbah yang dihasilkan langsung diangkut oleh petugas sanitasi yang berasal dari kegiatan vaksinasi, begitupun dengan limbah medis padat yang berasal dari setiap ruangan disimpan di tempat sampah pijakan yang dilapisi kantong berwarna kuning sedangkan non-medis dilapisi kantong warna hitam setelah 2/3 diangkut oleh petugas sanitasi. Pewadahan limbah medis menunjukan bahwa sebanyak $62,2 \%$ responden menggunakan kantong plastik kuning yang berlabel infeksius dan sebanyak 37,8 \% responden menggunakan kantong plastik kuning yang tidak berlabel infeksius. Penggunaan kantong plastik yang berbeda ini hanya tingkat pemahaman responden dan kebiasaan dalam pengelolaan limbah medis. menurutnya limbah medis yang bersumber dari aktivitas kegiatan medis harus disimpan di kantong plastik kuning sebagai tanda bahwa limbah tersebut adalah limbah medis. Hasil penelitian ini sesuai dengan penelitian yang dilakukan oleh Rahmatulah (2017) menunjukan limbah medis yang dihasilkan di Rumah Sakit JIH dalam proses pewadahan yang sudah disediakan tempat sampah berbahan fiber untuk pewadahan limbah medis dan non-medis serta safety box untuk pewadahan limbah B3, limbah yang dihasilkan dimusnahkan oleh pihak ketiga, (Rahmatullah, 2017).

Hasil observasi menunjukan bahwa proses penyimpanan limbah medis padat dilakukan setelah proses pengumpulan, limbah medis di simpan pada satu tempat penampungan sementara yang berada di lingkungan puskesmas. Proses penyimpanan limbah padat medis mencakup cara petugas menyimpan limbah padat medis pada tempat penyimpanan termasuk juga tempat atau wadah yang digunakan oleh puskesmas untuk menyimpan limbah medis serta lama waktu puskesmas menimbun limbah padat medis tersebut. Penyimpanan limbah medis padat dan limbah B3 di TPS kadang berlangsung 2 sampai 3 bulan kemudian diangkut oleh pihak ke-tiga yaitu PT Mitra Hijau untuk pengelolaan limbah lebih lanjut. Hasil penelitian ini sesuai dengan penelitian yang dilakukan oleh Vita zulfani (2018) menunjukan bahwa Insinerator di Rumah Sakit Umum Haji Medan tidak digunakan karena belum mendapatkan izin atau 
tidak layak pakai sehingga untuk pemusnahan limbah medis di serahkan kepada pihak ke-tiga.

\section{Pengangkutan, Pemusnahan Dan Pembuangan Akhir}

Pengelolaan limbah medis padat atau limbah vaksin Covid-19 di puskesmas SeKota Kendari pada tahap pengangkutan, pemusnahan dan pembuangan akhir diserakan kepada pihak ketiga yaitu PT Mitra Hijau. PT Mitra Hijau Asia atau MHA merupakan perusahaan pengumpul dan pengangkutan limbah berbahaya dan beracun (limbah B3) yang menerapkan konsep EHSC (environment, health, safety, compliance) sebagai kaidah pelaksanaan seluruh kegiatan mulai dari pembersihan, pengangkutan dan pengumpulan limbah B3, berlokasi di Makassar, Sulawesi Selatan dan telah memiliki izin dari Kementerian Lingkungan Hidup dan Kehutanan serta Kementerian Perhubungan, (Sugiyono, 2011).

\section{F. PENUTUP}

Tahap Pembuangan Limbah Medis di Puskesmas Kota Kendari (Limbah Vaksin Covid19) Peraturan Menteri Kesehatan Nomor: 1204/Menkes/SK/X/2004 dan Peraturan Menteri Lingkungan Hidup dan Kehutanan Nomor 56, Nomor 3 Republik Indonesia 2015 Proses pemilahan, penyimpanan, pengumpulan, pengangkutan, pemusnahan, dan pembuangan akhir sebanyak orang dengan melibatkan orang yaitu PT Mitra Hijau

\section{G. DAFTAR PUSTAKA}

Ajeng Purwanti, A. (2018). Pengelolaan Limbah Padat Bahan Berbahaya Dan Beracun (B3) Rumah Sakit di RSUD Dr.Soetomo Surabaya. Jurnal Kesehatan Lingkungan, 10(3), 291-298.

Andhani, R. 2018. Pengelolaan Limbah Meis Pelayanan Kesehatan. Banjarmasin: Gedung Rektorat Unlam

Calma. (2020). The COVID-19 Pandemic Is Generating Tons of Medical Waste: Sanitation Workers Need Personal Protective Equipment Too. article/3065049/coronaviruschina, diakses 20 April 2020.

Deni C. N. (2020). Tinjauan Kebijakan Pengelolaan Limbah Medis Infeksius Penanganan Corona Virus Disease 2019 (Covid-19). 1-12.

Kementrian Kesehatan RI. (2004). Nomor:1204/MENKES/SK/X/2004 tentang Persyaratan Kesehatan Lingkungan Rumah Sakit. Jakarta: Kementerian Kesehatan RI

Kulkarni. (2020). Asesmen kelestarian lingkungan dari pembuangan tanah di limbah padat kota yang dihasilkan di kota-kota India: Tinjauan Lingkungan.

Laylatul Hasanah dan Nelyta Oktavianisya. (2018). Gambaran Pengelolaan Limbah Medis Padat pada Pos Kesehatan Desa (Poskesdes) di Kecamatan Bluto. Jurnal Kesehatan Masyarakat, Vol 1 No 2. P-ISSN : 2614-5057. E-ISSN : 2614-5056

Menteri L.H. (2015). Peraturan menteri lingkungan hidup dan kehutanan Republik indonesia nomor p.56/menlhk-setjen/2015 Tentang tata cara dan persyaratan teknis pengelolaan limbah bahan berbahaya dan beracun dari fasilitas pelayanan kesehatan. 
Nghiem, L. D., Morgan, B., , \& Short, M. D. (2020). The Covid-19 Pandemic: Considerations for the Waste and Wastewater Services Sector. Chemical and Environmental Engineering, 1-5.

Ningrum dan Tualeka. (2019). Upaya Pengendalian Risiko Terhadap Unit Pengelolaan Limbah Medis Benda Tajam Di Rumah Sakit. Journal of Public Health Research and Community Health Development, 1(2), 98-108.

Nurwahyuni, N. T., 2020. Pengelolaan Limbah Medis Covid-19 Di Rumah Sakit. Jurnal Kesehatan Lingkungan. Vol. 10 No. 2 pp. 52-59

Peng, J., Wu, X., Wang, R., Li, C., Zhang, Q., \& Wei, D. (2020). Medical Waste Management Practice During The 2019-2020 Novel Coronavirus Pandemic: Experience In A General Hospital. American Journal of Infection Control, 48(8), 918-921.

Pratiwi, D., \& Maharani, C. (2013). Pengelolaan Limbah Medis Padat Pada Puskesmas Kabupaten Pati. Kesehatan Masyarakat, 9(1), 74-86.

Prasetiawan, T. (2020). Permasalahan Limbah Medis Covid-19 di Indonesia. 12(19).

Prihartanto. (2020). Perkiraan Timbulan Limbah Medi B3 (Bahan Berbahaya dan Beracun) Dari Rumah Sakit Penanganan Pasien Covid-19. Jurnal Sains Dan Teknologi Mitigasi Bencana, 15(1), 1-7.

Rahno, D., Roebijoso, J., dan Leksono, A. S. (2015). Pengelolaan Limbah Medis Padat Di Puskesmas Borong Kabupaten Manggarai Timur Propinsi Nusa Tenggara Timur. 6(1), 22-32.

Sarmin, Yusuf Sabilu, Nurmaladewi. 2021. Pengelolaan Limbah Medis Padat di Masa Pandemi Covid-19 Di Rumah Sakit Umum (RSU) Bahteramas Provinsi Sulawesi Tenggara. Preventif Journal Vol 5/No. 2/April/2021; p-ISSN: 2540-8283 eISSN: 2620-3294 DOI :

Satgas Sultra. (2020). Data Perkembangan Kasus Covid-19 di Sulawesi Tenggara.

Shi J., dan W. Z. (2020). Coronavirus: China struggling to deal with mountains of medical waste created by epidemic. www.scmp. com/news/china/society/

Sugiyono. (2011). Metode Penelitian Kuantitaf, Kualitatif dan $R$ \& D. Bandung: Alfabeta.

Vita zulfani. (2018). Pengelolaan Limbah Medis dan Non Medis Serta Pengetahuan, Sikap, Tindakan Perawat Di RSU Haji Medan. Hlm 1-103.

Widia Rahmatullah. (2017). Analisis SOP Pengolahan Limbah Medis dan Non Medis di Rumah Sakit Jogja International Hospital. Jurnal Ilmu Kesehatan Bhakti Setya Medika, Vol 2. ISSN Cetak : 2528-7621 dan ISSN Online: 2579-93801

Yu, H., Sun, X., Solvang, W. D., dan Zhao, X. (2020). Reverse Logistics Network Design for E ff ective Management of Medical Waste in Epidemic Outbreaks: Insights from the Coronavirus Disease 2019 ( Covid-19) Outbreak in Wuhan ( China). 